\title{
KINETIKA PERTUMBUHAN MIKROBIA DAN KEMUNDURAN MUTU BAKSO BERPELAPIS EDIBLE AKTIF BERBASIS PATI KIMPUL (Xanthosoma sagittifolium) PADA BERBAGAI KETEBALAN
}

\author{
Kinetics of Microbial Growth and Quality Deterioration of Meatballs Coated with Various Thickness of \\ Xanthosoma sagittifolium Starch-Based Active Edible Coating
}

Warkoyo' ${ }^{1}$, Budi Rahardjo², Djagal Wiseso Marseno³, Joko Nugroho Wahyu Karyadi²

\author{
${ }^{1}$ Jurusan Ilmu dan Teknologi Pangan, Universitas Muhammadiyah Malang, Jl. Raya Tlogomas No. 246, Malang 65144 \\ ${ }^{2}$ Jurusan Teknik Pertanian, Fakultas Teknologi Pertanian, Universitas Gadjah Mada, \\ J1. Flora No. 1, Bulaksumur, Yogyakarta 55281 \\ ${ }^{3}$ Jurusan Teknologi Pangan dan Hasil Pertanian, Fakultas Teknologi Pertanian, Universitas Gadjah Mada, \\ Jl. Flora No. 1, Bulaksumur, Yogyakarta 55281 \\ Email: warkoyo_umm@yahoo.co.id
}

\begin{abstract}
ABSTRAK
Kemunduran mutu bahan pangan yang terlapisi pelapis edible aktif tergantung kepada sifat produk, kondisi lingkungan, dan karakter pelapis. Karakter pelapis dipengaruhi oleh jenis dan jumlah dari bahan dasar penyusun, plasticizer, dan bahan aktif yang digunakan. Tujuan penelitian ini adalah untuk menentukan kinetika pertumbuhan mikrobia, dan kemunduran mutu bakso terlapisi edible aktif berbasis pati umbi kimpul (X. sagittifolium) dengan berbagai ketebalan. Perlakuan dalam penelitian ini adalah ketebalan pelapis edible yang berbeda $(0,43 ; 0,48 ; 0,53 ; 0,58 \mathrm{~mm})$. Parameter pengamatan meliputi jumlah mikrobia (total mikrobia dan Pseudomonas aeruginosa), kadar protein, TVB-N, susut bobot, dan tekstur. Hasil penelitian menunjukkan bahwa ketebalan pelapis edible aktif berpengaruh nyata terhadap populasi mikrobia, dan TVB-N, serta berpengaruh tidak nyata terhadap kadar protein, susut bobot, dan tekstur bakso. Pertumbuhan mikrobia (TPC dan P. aeruginosa) berubah secara eksponensial dengan laju peningkatan sebesar 0,0490,055 per jam untuk TPC, dan 0,071-0,075 per jam untuk $P$. aeruginosa atau sebesar 0,026 per mm.jam kali ketebalan. Kadar TVB-N bakso berubah secara linier dengan laju peningkatan sebesar 0,132-0,153 mg/100g.jam atau sebesar $0,206 \mathrm{mg} / 100 \mathrm{~g} . \mathrm{mm}$.jam kali ketebalan. Pelapis edible aktif berbasis pati $X$. sagittifolium yang diinkorporasi kalium sorbat dengan tebal $0,43 \mathrm{~mm}$ dapat meningkatkan umur simpan bakso sampai 4 kali lebih lama dibandingkan bakso tanpa pelapis.
\end{abstract}

Kata kunci: Ketebalan pelapis edible aktif, kinetika kemunduran mutu

\begin{abstract}
Quality deterioration of food material with active edible coated depends on product properties, environment and properties of coating. Properties of coating are influenced by the type and amount of the basic constituent materials, plasticizers, and active coating ingredient. The objective of this research was to determine the kinetics of microbial growth, and quality deterioration of $X$. sagittifolium starch-based coated meatball with various thicknesses. The treatments tested in this study were thickness of edible coatings $(0.43 ; 0.48 ; 0.53 ; 0.58 \mathrm{~mm})$. Observation parameters were the number of microbes (total microbial, and Pseudomonas aeruginosa), protein content, TVB-N, water losses, and texture. The results showed that active edible coatings thickness significantly affected of microbes number, and TVB-N, but did not affect protein content, water losses, and meatball texture. Microbial growth (TPC and P. aeruginosa) changed exponentially with the rate of increase of 0.049 to 0.055 per hour for TPC and from 0.071 to 0.075 per hour for $P$. aeruginosa or 0.026 per mm.hour times the thickness. TVB-N content changed linearly with the rate of increase of 0.132 to $0.153 \mathrm{mg} / 100 \mathrm{~g}$.hour or $0.206 \mathrm{mg} / 100 \mathrm{~g} . \mathrm{mm}$.hour times the thickness. X. sagittifolium starch-based active edible coating with potassium sorbate as active ingredient and $0.43 \mathrm{~mm}$ coating thickness could prolong meatball shelf life up to 4 times longer than control.
\end{abstract}

Keywords: Thickness of active edible coating, kinetics of quality deterioration 


\section{PENDAHULUAN}

Pati kimpul mengandung amilosa 35,34\%, dua kali lebih besar dibandingkan kandungan amilosa pati ubi kayu (Perez dkk., 2005) sehingga apabila dibuat pelapis edible akan lebih kuat dan fleksibel dibandingkan pelapis dari pati ubi kayu. Ketebalan pelapis edible aktif sebagai salah satu faktor yang dapat mempengaruhi sifat pelapis. Ketebalan pelapis edible aktif yang berbeda akan memberikan sifat pelapis yang berbeda. Sifat pelapis yang berbeda, apabila diaplikasikan pada produk pangan yang sama akan memberikan dampak mikrobia, kimia dan fisik yang berbeda. Konsentrasi kalium sorbat yang berbeda pada pelapis edible berpengaruh nyata terhadap laju pertumbuhan mikrobia, laju perubahan kadar total volatile basic nitrogen (TVB-N) dan perubahan tingkat kekerasan produk pangan (Warkoyo dkk., 2015). Perubahan mikrobia berhubungan dengan perubahan kimia dan fisik produk selama penyimpanan sebagaimana yang dikemukakan Ojagh dkk. (2010) yang menyatakan bahwa ada korelasi antara nilai mikrobia dan kimia.

Pelapis edible aktif diaplikasikan pada bakso sebagai usaha untuk mempertahankan nutrisi dan kualitas fisik selama penyimpanan, serta menghambat kerusakan mikrobia. Bakso tanpa kemasan antimikrobia yang disimpan pada suhu ruang hanya bertahan \pm 24 jam, sedangkan bakso dengan kemasan antimikrobia dapat diperpanjang umur simpannya 2 kali lebih lama (Warsiki dkk., 2009), dan 4 kali lebih lama untuk bakso berpelapis edible aktif (Warkoyo dkk., 2015). Pelapis edible aktif dapat berperan dalam menghambat pertumbuhan mikrobia. Ketebalan pelapis edible aktif yang berbeda akan memberikan pengaruh yang berbeda terhadap kualitas produk selama penyimpanan.

Tujuan kajian ini adalah untuk mendapatkan kinetika pertumbuhan mikrobia, dan kemunduran mutu kimia dan fisik bakso yang terlapisi edible aktif berbasis pati umbi kimpul ( $X$. sagittifolium) dengan berbagai ketebalan.

\section{METODE PENELITIAN}

\section{Landasan Teori}

Perubahan produk pangan selama penyimpanan, akan terjadi pada suatu kecepatan yang tergantung pada beberapa faktor, misalnya adanya pemanasan akan berpengaruh terhadap kecepatan dimana konsentrasi beberapa jenis komponen dikurangi (Heldman dan Singh, 1981). Menurut Koswara (2002), bahan pangan akan mengalami penurunan kualitas atau nilai gizi. Apabila rentang waktu penyimpanan relatif singkat, pertumbuhan mikrobia memasuki fase log (awal fase log), maka kinetika perubahan kadar protein, TVB-N, susut bobot, dan tekstur mengikuti reaksi orde nol (Persamaan 1).

$$
\frac{-d(M u t u)}{d t}=k
$$

dan apabila diintegralkan hasilnya dapat dituliskan dalam Persamaan 2.

$(M u t u)_{t}=(M u t u)_{0}+k t$

dimana $d($ Mutu $) / d t$ : perubahan mutu terhadap waktu $\mathrm{t}, k$ : konstanta laju perubahan mutu (unit mutu/waktu), (Mutu) : kadar mutu pada waktu t, dan (Mutu) ${ }_{0}$ : kadar mutu mulamula.

Teori kinetika, disamping dapat digunakan untuk menjelaskan perubahan mutu bahan, juga dapat digunakan untuk menjelaskan perubahan jumlah mikrobia. Pertumbuhan mikrobia pada tahap awal penyimpanan berada pada fase log, dan pertumbuhannya menurut Labuza (Koswara, 2002) mengikuti reaksi orde satu sebagaimana dinyatakan dalam Persamaan 3.

$$
\frac{d(M)}{d t}=k^{\prime} M
$$

dan hasil integralnya dapat dituliskan dalam Persamaan 4.

$$
M_{t}=M_{0} e^{k^{\prime} t}
$$

dimana $\mathrm{M}_{\mathrm{t}}$ : jumlah mikrobia pada waktu $\mathrm{t}, \mathrm{M}_{0}$ : jumlah mikrobia mula-mula, dan $\mathrm{k}^{\prime}$ : konstanta laju pertumbuhan sel mikrobia.

\section{Bahan}

Bakso daging sapi sebagai obyek pelapisan dibuat dengan menambahkan tepung aren sebesar 50\% dari berat daging, serta bumbu-bumbu seperti bawang putih, dan garam dapur masing-masing sebanyak 5\% dari berat daging sapi. Pati umbi kimpul (X. sagittifolium) ukuran 100 mesh yang digunakan untuk pelapis edible dan kalium sorbat (Produk Linyi RRC) sebagai bahan aktif diperoleh dari Laboratorium Ilmu dan Teknologi Pangan Universitas Muhammadiyah Malang.

\section{Preparasi Larutan Pelapis Edible Aktif}

Larutan pelapis edible aktif disiapkan dengan melarutkan pati $X$. sagittifolium sejumlah 2,0-3,5\% ke dalam $100 \mathrm{~mL}$ air destilat untuk mendapatkan ketebalan pelapis bervariasi $(0,43 ; 0,48 ; 0,53$; dan $0,58 \mathrm{~mm})$, menambahkan kalium sorbat $0,6 \%(\mathrm{~b} / \mathrm{v})$, dan gliserol $0,8 \%$ pati, kemudian dipanaskan di atas hotplate stirrer sampai terjadi gelatinisasi, yaitu pada suhu $\pm 85^{\circ} \mathrm{C}$. Gelatinisasi dipertahankan selama 5 menit. Khusus untuk pengukuran ketebalan pelapis, larutan pelapis ditambah pewarna makanan (merah). Pengukurannya 
menggunakan mikroskop cahaya yang dilengkapi kaca micrometer pada lensa okulernya.

\section{Pelapisan Edible Aktif Pada Bakso}

Cara pencelupan digunakan untuk pelapisan edible aktif pada bakso. Pencelupan dilakukan pada kondisi larutan pelapis masih panas (suhu $\pm 75^{\circ} \mathrm{C}$ ) selama 5 menit. Penyimpanan bakso yang telah dilapisi dan ditiriskan, dalam cup plastik (steril) pada suhu kamar untuk dilakukan pengamatan secara periodik terhadap parameter pengamatan yang meliputi populasi mikrobia, kadar protein, TVB-N, susut berat, dan tekstur. Batas penerimaan konsumen digunakan sebagai acuan dalam pengamatan, yaitu dengan tanda munculnya lendir atau adanya bintik-bintik noda pada permukaan bakso.

\section{Total Mikrobia dan Pseudomonas aeruginosa (Yousef dan Carlstrom, 2003)}

Total mikrobia dan P. aeruginosa dihitung menggunakan metode total plate count (TPC). Sampel (yang telah lumat) sebanyak $1 \mathrm{~g}$ diencerkan dengan $9 \mathrm{ml}$ air destilat, dan dilakukan homogenisasi. Pengenceran bertingkat mulai dari $10^{-1}$ sampai $10^{-5}$ dibuat. Satu $\mathrm{ml}$ dari masing-masing pengenceran diambil untuk dimasukkan ke petridish berisi media nutrient agar (NA) untuk total mikrobia. Satu ml lagi dimasukkan petridish berisi media PSA untuk P. aeruginosa. Semua biakan diinkubasi selama 48 jam pada suhu $\pm 37^{\circ} \mathrm{C}$, sebelum dilakukan penghitungan koloni.

\section{Protein (AOAC, 2005)}

Metode mikro Kjeldahl (AOAC, 2005) digunakan untuk menentukan protein kasar. Sampel bakso (yang telah lumat) 0,5 g ditambah $\mathrm{H}_{2} \mathrm{SO}_{4} 2 \mathrm{ml}$, dan campuran $\mathrm{Na}_{2} \mathrm{SO}_{4}: \mathrm{HgO}$ (20:1) sejumlah 2 g. Bahan dipanaskan (30 menit), dicuci dan dididihkan lagi (30 menit). Aquades sejumlah 5-10 ml, dan $\mathrm{NaOH}: \mathrm{Na}_{2} \mathrm{~S}_{2} \mathrm{O}_{3}$ (40:5) sejumlah 6-15 ml ditambahkan, kemudian dilakukan pengenceran lagi. Destilasi dilakukan, destilat yang diperoleh dititrasi dengan $0,02 \mathrm{~N} \mathrm{HCl}$. Total $\mathrm{N}$ dan $\%$ protein bahan dapat dihitung berdasarkan volume $\mathrm{HCl}$ yang dibutuhkan.

\section{TVB-N (Chomnawang dkk., 2007)}

Komponen TVB-N ditentukan dengan metode Suvanich dkk. (2000) yang dimodifikasi. Ringkasnya adalah bakso yang telah dilumatkan $(5 \mathrm{~g})$, direndam selama 5 menit dalam $15 \mathrm{ml}$ TCA 5\%. Pemisahan dilakukan dengan sentrifus (5000 rpm) selama 10 menit. Supernatant tertampung (5 $\mathrm{ml})$ ditambah $\mathrm{NaOH} 2 \mathrm{M}(5 \mathrm{ml})$ untuk dilakukan destilasi. Destilat ditampung dalam labu yang telah berisi $\mathrm{HCl} 0,01 \mathrm{~N}$ $(15 \mathrm{ml})$ sampai volume $40 \mathrm{ml}$ tercapai. Selanjutnya indikator phenol red 3 tetes ditambahkan, sebelum dititrasi dengan
$\mathrm{NaOH}$ 0,01 N sampai berwarna pink. Nilai TVB-N ditentukan berdasarkan kebutuhan $\mathrm{NaOH}$ untuk titrasi.

\section{Tekstur}

Tekstur (kekerasan) bakso diukur secara periodik menggunakan Tensile Strength Instrument, TSI (Imada ZP200N, Japan). Sampel bakso berbentuk kubus (panjang rusuk $\pm 20 \mathrm{~mm}$ ) disiapkan, kemudian diletakkan di atas meja kerja TSI untuk pengukuran tekstur.

\section{Susut Bobot (Suppakul dkk., 2010)}

Susut bobot didapat dengan cara menimbang sampel bakso secara periodik dengan menggunakan timbangan analitik digital (Ohaus Corp Pine Brooks). Susut bobot (\%) dinyatakan sebagai \{(berat bakso awal - berat bakso pada waktu t)/berat bakso awal\} 100 .

\section{Analisis Data}

Data dianalisis menggunakan analisa variansi (ANOVA), dan uji beda rata-rata Duncan (DMRT) pada taraf 5\% sebagai uji lanjutnya dengan bantuan program Microsoft Office Excel. Kinetika pertumbuhan mikrobia dan kemunduran mutu produk diperoleh dengan jalan pengeplotan data terhadap waktu pengamatan (menggunakan Microsoft Office Excel) untuk mendapatkan koefisien arah. Koefisien kinetika dari masing-masing parameter (Persamaan 2 dan 4) diperoleh dengan cara pengeplotan koefisien arah dan ketebalan pelapis edible aktif dalam grafik.

\section{HASIL DAN PEMBAHASAN}

\section{Total Mikrobia dan P. aeruginosa}

Hasil analisis ragam menunjukkan bahwa laju perubahan total mikrobia (TPC) dan P. aeruginosa dipengaruhi oleh ketebalan pelapis edible aktif. Populasi mikrobia pada bakso selama penyimpanan mengalami peningkatan, dan peningkatannya secara eksponensial (Gambar 1 dan 2).

Laju peningkatan populasi mikrobia (k-TPC) pada bakso selama penyimpanan pada ketebalan pelapis edible aktif 0,43-0,53 mm relatif sama, yaitu berkisar 0,049-0,051 per jam, sedangkan k-TPC untuk ketebalan 0,58 mm adalah 0,055 per jam. Hal ini mengindikasikan bahwa ketebalan pelapis edible aktif $0,58 \mathrm{~mm}$ menghasilkan penghambatan terhadap pertumbuhan mikrobia yang lebih kecil dibandingkan ketebalan pelapis $0,43-0,53 \mathrm{~mm}$. Ketebalan pelapis edible aktif yang semakin besar menyebabkan volume pelapis semakin besar dan hal ini memungkinkan jumlah bahan aktif yang dikandung semakin besar, yaitu $0,8 \mathrm{ml}$ setiap selisih satu level perlakuan atau sebesar $0,025 \mathrm{ml} / \mathrm{cm}^{2}$, akibatnya kemampuan dalam menghambat pertumbuhan mikrobia 
dimungkinkan juga semakin besar. Keefektifan pelapis antimikrobia dalam menghambat pertumbuhan mikrobia tergantung kepada konsentrasi yang ditambahkan (Neetoo dkk., 2010). Namun yang perlu mendapat perhatian juga adalah kemungkinan adanya distribusi senyawa aktif yang tidak merata pada pelapis yang tebal, sehingga kemampuan penghambatan pelapis terhadap pertumbuhan mikrobia tidak merata di seluruh permukaan, akibatnya peluang bagi mikrobia untuk tumbuh dan berkembang juga besar.

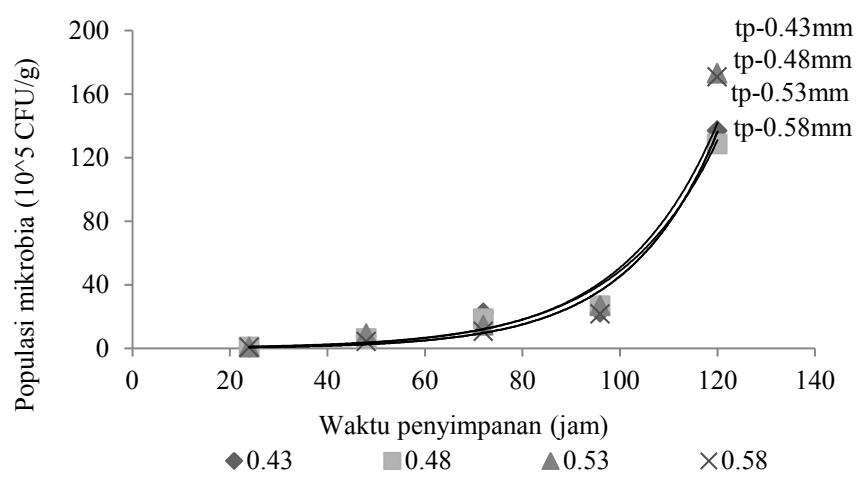

Gambar 1. Total mikrobia pada bakso yang terlapisi edible aktif dengan berbagai ketebalan pelapis

Produk berpelapis edible aktif dengan berbagai ketebalan, apabila berpedoman pada batas penerimaan TPC, yaitu $10^{6} \mathrm{CFU} / \mathrm{g}$ (Duan dkk., 2010), memiliki umur simpan 96 jam atau 4 kali lebih lama dibandingkan dengan bakso tanpa pelapis, yaitu hanya \pm 24 jam (Warsiki dkk., 2009).

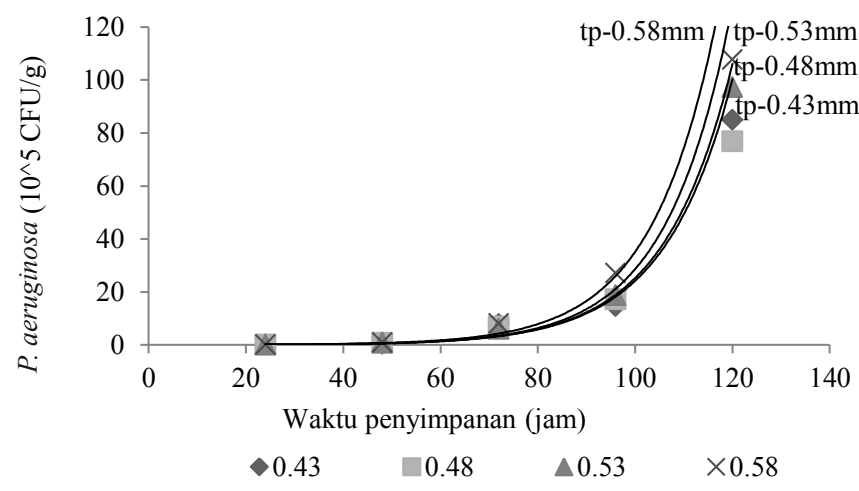

Gambar 2. Populasi P. aeruginosa (Psa) pada bakso yang terlapisi edible aktif dengan berbagai ketebalan pelapis

Ketebalan pelapis edible aktif yang semakin besar menyebabkan pertumbuhan mikrobia semakin cepat. Hal ini juga dapat diperhatikan dari nilai konstanta pertumbuhannya (k-TPC dan k-Psa) sebagaimana hasil penelitian tertuang pada
Tabel 1. Ketebalan pelapis edible aktif yang semakin besar dapat menghasilkan k-TPC dan k-Psa yang semakin besar. Nilai k-TPC dan k-Psa yang semakin besar menunjukkan pertambahan populasi mikrobia semakin cepat, akibatnya umur simpan produk semakin pendek, dan sebaliknya nilai konstanta pertumbuhan yang semakin kecil, pertambahan populasi mikrobia semakin lambat, akibatnya umur simpan produk semakin panjang. Fenomena ini mengindikasikan bahwa ketebalan pelapis edible aktif yang semakin besar menyebabkan penghambatan terhadap pertumbuhan mikrobia yang semakin kecil. Hubungan antara pertumbuhan mikrobia (total mikrobia, (TPC, CFU/g) dan P. aeruginosa (Psa, $\mathrm{CFU} / \mathrm{g})$ dan ketebalan pelapis edible aktif $(\partial, \mathrm{mm})$ dinyatakan dalam Persamaan 5.

$T P C_{0} e^{(0,026(\partial)+0,038) t}$

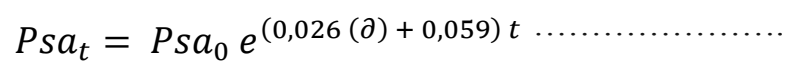

Tabel 1. Konstanta perubahan total mikrobia (k-TPC), $P$. aeruginosa (k-Psa), dan TVB-N (k-TVB) bakso yang terlapisi edible aktif dengan berbagai ketebalan pelapis

\begin{tabular}{ccccccc}
\hline Tebal pelapis & \multicolumn{2}{c}{$\begin{array}{c}\text { k-TPC } \\
\text { (per jam) }\end{array}$} & \multicolumn{2}{c}{$\begin{array}{c}\text { k-Psa } \\
\text { (per jam) }\end{array}$} & \multicolumn{2}{c}{$\begin{array}{c}\text { k-TVB } \\
\text { (mg/100g.jam) }\end{array}$} \\
\hline $0,43 \mathrm{~mm}$ & 0,051 & a & 0,071 & a & 0,132 & a \\
$0,48 \mathrm{~mm}$ & 0,049 & a & 0,071 & a & 0,138 & ab \\
$0,53 \mathrm{~mm}$ & 0,050 & a & 0,075 & b & 0,151 & $\mathrm{~b}$ \\
$0,58 \mathrm{~mm}$ & 0,055 & b & 0,074 & b & 0,153 & b \\
\hline
\end{tabular}

Keterangan: Angka-angka yang diikuti huruf yang sama pada kolom yang sama menunjukkan tidak berbeda nyata menurut uji DMRT $(\alpha$ $=0,05)$

Apabila dibandingkan dengan bakso tanpa pelapis yang mempunyai nilai $\mathrm{k}$-TPC sebesar 0,10 per jam, adanya pelapis edible aktif (k-TPC 0,049-0,055 per jam) dapat mereduksi pertumbuhan mikrobia sebesar 2 kalinya, akibatnya umur simpan produk dapat ditingkatkan. Beberapa penelitian yang sejalan dengan hasil tersebut adalah Lu dkk. (2010) menyampaikan bahwa pertumbuhan mikrobia pada filet yang dilapisi alginat dengan inkorporasi cinnamon selama penyimpanan (suhu $4{ }^{\circ} \mathrm{C}$ ) mengalami penghambatan, akibatnya mutu filet dapat dipertahankan. Juck dkk. (2010) menyampaikan bahwa pelapis alginat dengan berbagai bahan aktif yang diaplikasikan pada ayam rebus (berkadar air tinggi) memberikan penghambatan yang lebih rendah dibandingkan pada ayam panggang (Tabel 2). 
Tabel 2. Populasi mikrobia pada ayam, dan waktu pencapaian batas penerimaan mikrobia pada keju akibat pelapisan

\begin{tabular}{lccccc}
\hline \multirow{2}{*}{\begin{tabular}{l} 
Perlakuan \\
\cline { 2 - 6 }
\end{tabular}} & \multicolumn{2}{c}{$\begin{array}{c}\text { Populasi mikrobia, log CFU/g } \\
\text { (Juck dkk. 2000) }\end{array}$} & \multicolumn{2}{c}{ Waktu pencapaian batas penerimaan, hari (Di Piero dkk. } \\
\cline { 2 - 6 } & A. rebus & A. panggang & B. mesopilik & B. psikrotropik & BAL \\
\hline Tanpa pelapis & 7,9 & 6,5 & 7 & 214 & 21 \\
Dengan pelapis & $3,0-4,9$ & $1,5-1,7$ & $21 *$ & $21 *$ & $21 *$ \\
\hline
\end{tabular}

Keterangan : A = ayam; $\mathrm{B}=$ bakteri; * batas penerimaan populasi mikrobia belum tercapai

Berdasarkan batas penerimaan populasi mikrobia, pelapis chitosan-whey protein (Cwp) menurut Di Piero dkk. (2011) dapat memperpanjang umur simpan keju secara efektif (Tabel 2).

\section{Protein}

Hasil penelitian menunjukkan bahwa kadar protein bakso mengalami penurunan dengan bertambahnya waktu penyimpanan (Gambar 3), tetapi berdasarkan analisis ragam kadar protein bakso tidak dipengaruhi oleh ketebalan pelapis edible aktif. Penurunan kadar protein cenderung lebih besar pada produk dengan ketebalan pelapis edible aktif yang lebih tinggi. Hal ini mengindikasikan bahwa protein bakso sebagai subtrat pertumbuhan mikrobia, relatif berkurang dengan semakin besarnya ketebalan pelapis edible aktif.

Apabila diperhatikan lebih jauh, laju penurunan protein (k-protein) cenderung semakin besar dengan semakin besar ketebalan pelapis edible aktif (Gambar 4). Hal ini mengindikasikan bahwa proses dekomposisi protein cenderung semakin cepat, dan ini sejalan dengan pertumbuhan mikrobia yang semakin cepat karena adanya pelapis edible aktif yang semakin tebal. Hubungan antara penurunan kadar protein (protein, \%) dan ketebalan pelapis edible aktif $(\partial$, $\mathrm{mm}$ ) dalam pelapis edible aktif dinyatakan dalam Persamaan 6.

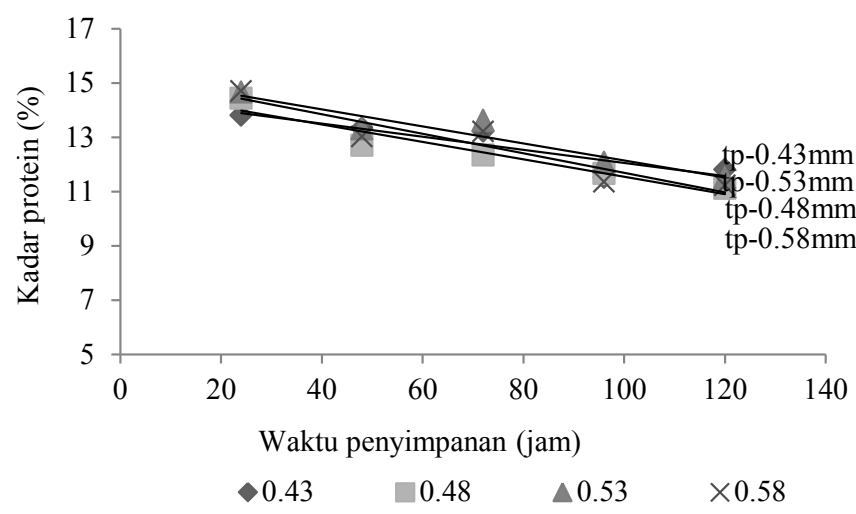

Gambar 3. Kadar protein bakso yang terlapisi edible aktif dengan berbagai ketebalan pelapis

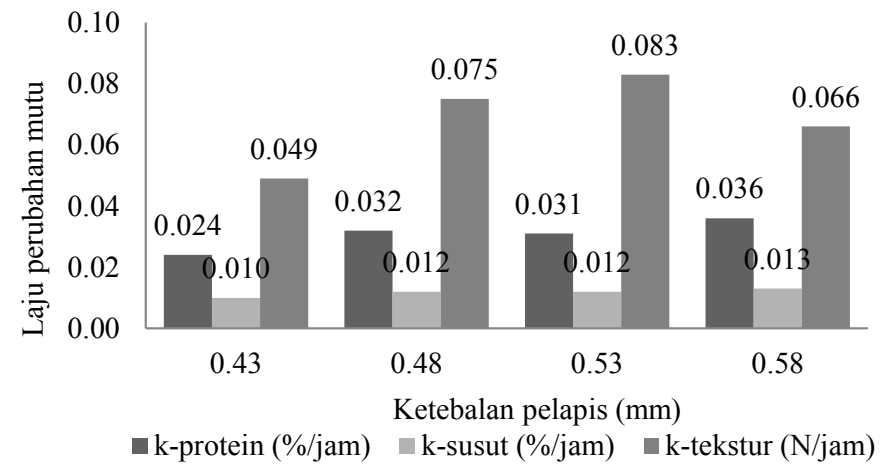

Gambar 4. Laju perubahan kadar protein, susut bobot, dan tekstur bakso berpelapis edible aktif pada berbagai ketebalan

Protein $_{t}=$ Protein $_{0}-(0,07(\partial)+0,004) t$

Akkose dan Aktas (2008) menyatakan bahwa selama penyimpanan degradasi protein bertambah, dan protein akan terdekomposisi dengan menghasilkan senyawa-senyawa volatil, sebagai indikasi adalah nilai TVB-N yang semakin meningkat. Mahmoud dkk. (2006) menyatakan bahwa kadar protein akan tetap tinggi manakala proses dekomposisi filet dapat ditunda. Pelapisan pada ikan yang disimpan pada suhu dingin menurut Song dkk. (2011), dapat mengurangi kerusakan kimiawi, dibandingkan dengan tanpa pelapisan.

\section{TVB-N}

Total volatile basic nitrogen (TVB-N) bakso mengalami peningkatan dengan bertambahnya waktu penyimpanan (Gambar 5), dan berdasarkan analisis ragam peningkatan kandungan TVB-N bakso dipengaruhi oleh ketebalan pelapis edible aktif.

Kandungan TVB-N bakso selama penyimpanan mengalami peningkatan, dan peningkatannya semakin besar dengan adanya ketebalan pelapis edible aktif yang semakin besar. Hal ini juga dapat dilihat dari nilai konstanta perubahan TVB-N (k-TVB), ketebalan pelapis edible aktif yang semakin besar menghasilkan nilai k-TVB yang semakin besar (Tabel 1). Kenyataan tersebut mengindikasikan bahwa pelapis edible aktif yang semakin tebal menyebabkan pertumbuhan 
mikrobia semakin cepat, proses dekomposisi protein yang semakin cepat, kadar TVB-N semakin besar, akibatnya penolakan konsumen terhadap bakso menjadi lebih cepat. Perlu diketahui bahwa nilai k-TVB kontrol (tanpa pelapis) sebesar 1,0565 mg/100g.jam, artinya keberadaan pelapis edible aktif dalam penelitian ini sudah dapat mereduksi laju produksi TVB-N antara 6,91-8,59 kali. Hubungan antara perubahan TVB-N (mg/100 g) dan ketebalan pelapis edible aktif $(\partial, \mathrm{mm})$ dalam pelapis edible aktif dinyatakan dalam Persamaan 7.

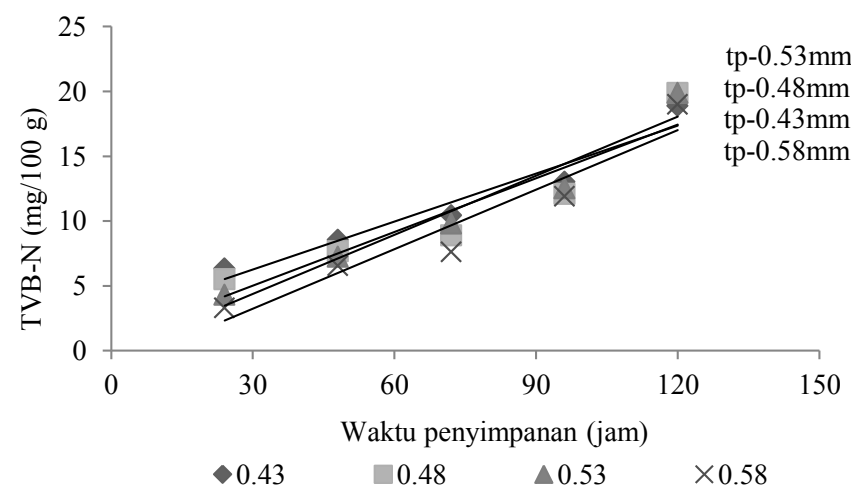

Gambar 5. Kandungan TVB-N bakso yang terlapisi edible aktif dengan berbagai ketebalan pelapis edible aktif

$T V B_{-} N_{t}=T V B \_N_{0}+(0,206(\partial)+0,037) t$

Nilai TVB-N produk selama penyimpanan mengalami peningkatan, seperti yang terjadi pada daging sapi (Akkose dan Aktas, 2008), dan filet ikan yang disimpan pada suhu $4{ }^{\circ} \mathrm{C}$ (Chomnawang dkk., 2007). Peningkatan nilai TVB-N tersebut dapat dihambat dengan adanya pelapis aktif, seperti pada filet ikan dengan pelapis chitosan (Ojagh dkk., 2010; Duan dkk., 2010), dan filet ikan dengan pelapis alginatchinamon (Lu dkk., 2010).

\section{Susut Bobot}

Berat bakso berpelapis edible aktif selama penyimpanan mengalami penyusutan, dan penyusutannya cenderung meningkat dengan bertambahnya ketebalan pelapis edible aktif (Gambar 6), berdasarkan analisis ragam susut bobot bakso tidak dipengaruhi oleh ketebalan pelapis edible aktif.

Ketebalan pelapis edible aktif yang semakin besar menghasilkan k-susut yang cenderung semakin besar (Gambar 4). Hal ini dapat terjadi karena dengan meningkatnya ketebalan pelapis edible aktif, jumlah bahan aktif semakin besar, peluang terjadinya modifikasi struktur jaringan pati semakin besar, permeabilitas semakin besar, penghambatan pelepasan uap air ke lingkungan cenderung semakin kecil, akibatnya transmisi uap air dari produk ke lingkungan

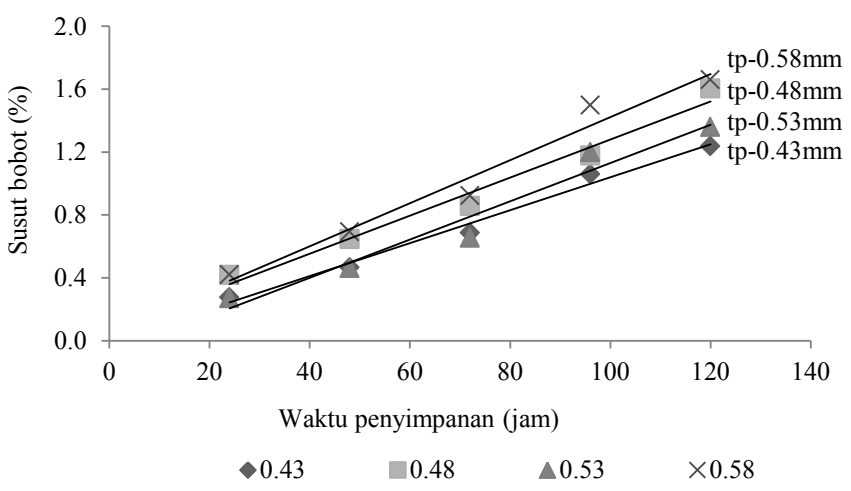

Gambar 6. Susut bobot bakso yang terlapisi edible aktif dengan berbagai ketebalan pelapis edible aktif

melalui pelapis edible cenderung bertambah. Menurut Song dkk. (2011) menyatakan bahwa pelapisan alginat pada ikan yang disimpan pada suhu $4^{\circ} \mathrm{C}$ dapat menghambat kehilangan air, dibandingkan dengan tanpa pelapisan. Hubungan antara penyusutan berat bakso (Susut bobot, \%) dan ketebalan pelapis edible aktif $(\partial, \mathrm{mm})$ dalam pelapis edible aktif dinyatakan dalam Persamaan 8.

Susut bobot $_{t}=(0,018 \partial+0,002) t$

Kenyataan ini sejalan dengan penambahan kalium sorbat pada edible film berbasis pati $X$. sagittifolium sebagaimana yang dilaporkan Warkoyo dkk. (2014) yang menyatakan bahwa penambahan kalium sorbat pada edible film yang semakin meningkat menyebabkan transmisi uap air yang semakin meningkat pula. Penambahan kalium sorbat yang semakin tinggi pada film berbasis pati umbi rambat akan menghasilkan permeabilitas uap air yang semakin tinggi (Shen dkk., 2010). Penambahan bahan aktif (ekstrak biji anggur dan tymol) dapat meningkatkan permeabilitas uap air dari film yang dibentuk (Lim dkk., 2010).

\section{Tekstur}

Tekstur (kekerasan) bakso berpelapis edible aktif mengalami peningkatan selama penyimpanan, dan peningkatannya cenderung bertambah dengan semakin besarnya ketebalan pelapis edible aktif (Gambar 7), berdasarkan analisis ragam tekstur bakso tidak dipengaruhi oleh ketebalan pelapis edible aktif. Hal ini mengindikasikan bahwa ketebalan pelapis edible aktif yang semakin besar dapat menyebabkan penghambatan kerusakan produk oleh mikrobia semakin besar, peluang untuk terjadinya kerusakan oleh mikrobia cenderung semakin kecil, bangunan/formasi matrik polimer yang ada tetap kokoh, kemampuan menahan tekanan dari luar besar, akibatnya bakso berpelapis edible aktif dengan ketebalan tinggi mempunyai tekstur yang tinggi. 
Ojagh dkk. (2010) melaporkan bahwa pertumbuhan mikrobia pada filet berpelapis edible aktif lambat sehingga kerusakannya dapat diminimalisir, sementara filet tanpa pelapis mengalami kerusakan.

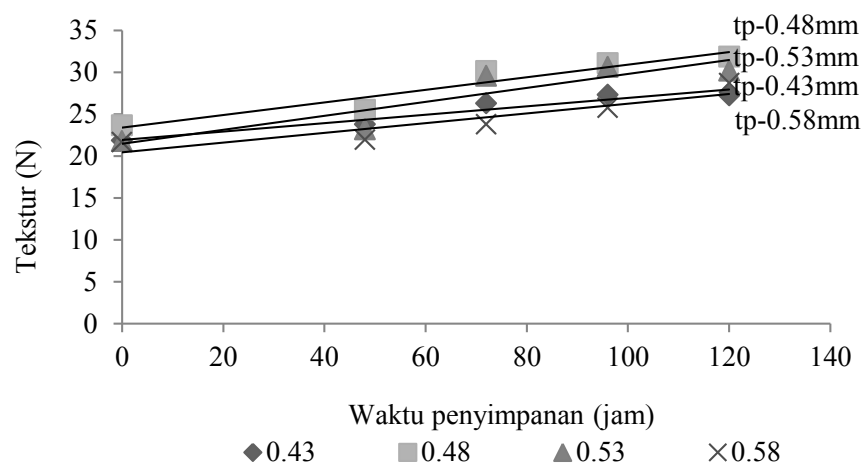

Gambar 7. Tekstur bakso yang terlapisi edible aktif dengan berbagai ketebalan pelapis edible aktif

Laju peningkatan tekstur yang dihasilkan cenderung semakin besar dengan adanya ketebalan pelapis edible aktif yang semakin bertambah (Gambar 4). Hal ini mengindikasikan bahwa kemunduran mutu bakso (secara fisik) terhambat dengan adanya ketebalan pelapis edible aktif yang semakin besar. Hubungan antara peningkatan tekstur (Tekstur, N) dan ketebalan pelapis edible aktif $(\partial, \mathrm{mm})$ dalam pelapis edible aktif dinyatakan dalam Persamaan 9.

Tekstur $_{t}=$ Tekstur $_{0}+(0,07 \partial+0,030) t$

Di Piero dkk. (2011) menyatakan bahwa pelapis chitosan-whey protein (Cwp), disamping dapat menghambat pertumbuhan mikrobia, juga dapat mempertahankan tekstur keju dengan baik. Ojagh dkk. (2010) melaporkan bahwa pelapis edible yang diaplikasikan pada filet dapat mempertahankan teksturnya selama penyimpanan, dibandingkan dengan filet tanpa pelapis edible.

\section{KESIMPULAN}

Ketebalan pelapis edible aktif dengan kisaran 0,43-0,58 $\mathrm{mm}$ berpengaruh nyata terhadap laju pertumbuhan mikrobia, dan perubahan TVB-N, serta berpengaruh tidak nyata terhadap kadar protein, susut bobot, dan tekstur bakso. Pertumbuhan mikrobia (TPC, dan P. aeruginosa) selama penyimpanan berubah secara eksponensial dengan laju peningkatan sebesar 0,049-0,055 per jam untuk TPC dan 0,071-0,075 per jam untuk $P$. aeruginosa atau 0,026 per mm.jam kali ketebalan pelapis edible aktif. Kadar TVB-N bakso berubah secara linier dengan laju peningkatan sebesar 0,132-0,153 mg/100g. jam atau 0,206 mg/100g.mm.jam kali ketebalan pelapis edible aktif. Pelapis edible aktif berbasis pati $X$. sagittifolium yang diinkorporasi kalium sorbat dengan tebal 0,43 mm dapat meningkatkan umur simpan bakso sampai 4 kali lebih lama dibandingkan bakso tanpa pelapis.

\section{DAFTAR PUSTAKA}

Alkose, A. dan Aktas, N. (2008). Determination of glass transition temperature of beef and effects of various cryoprotective agents on some chemical changes. Meat Science 80: 875-878.

AOAC. (2005). Official Methods of Analysis (14 $4^{\text {th }}$ ed). Association of Official Analytical Chemists. Washington DC.

Chomnawang, C., Nantachai, K., Yongsawatdigul, J., Thawornchinsombut, S. dan Tungkawachara, S. (2007). Chemical and biochemical changes of hybrid catfish fillet stored at $4{ }^{\circ} \mathrm{C}$ and its gel properties. Food Chemistry 103: 420-427.

Di Pierro, P., Sorrentino, A., Mariniello, L., Giosafatto, C.V.L. dan Porta, R. (2011). Chitosan/whey protein film as active coating to extend Ricotta cheese shelf-life. LWTFood Science and Technology 44: 2324-2327.

Duan, J., Jiang, Y., Cherian, G. dan Zhao, Y. (2010). Effect of combined chitosan-krill oil coating and modified atmosphere packaging on the storability of cold-stored lingcod (Ophiodon elongates) fillets. Food Chemistry 122: $1035-1042$.

Heldman, D.R. dan Singh, R.P. (1981). Food process Engineering, $2^{\text {nd }}$ edn. The AVI Publishing Company, Inc., Westport, Connecticut.

Juck, G., Neetoo, H. dan Chen, H. (2010). Application of an active alginate coating to control the growth of Listeria monocytogenes on poached and deli turkey products. International Journal of Food Microbiology 142: 302308.

Koswara, S. (2002). Penerapan persamaan Arhennius untuk menduga umur simpan produk dan bahan pangan. Jurnal Teknologi dan Industri Pangan 13 (2): 197-203.

Lim, G.O., Jang, S.A. dan Song, K.B. (2010). Physical and antimicrobial properties of Gelidium corneum/nanoclay composite film cantaining grapefruit seed extract or thymol. Journal of Food Engineering 98: 415-420.

Lu, F., Ding, Y., Ye, X. dan Liu, D. (2010). Cinnamon and nisin in alginate-calcium coating maintain quality of fresh northern snakehead fish fillets. LWT-Food Science and Technology 43: 1331-1335. 
Mahmoud, B.S.M., Yamazaki, K., Miyashita, K., Shin, I.I. dan Suzuki, T. (2006). A new technology for fish preservation by combined treatment with electrolyzed $\mathrm{NaCl}$ solutions and essential oil compounds. Food Chemistry 99: 656-662.

Neetoo, H., Ye, M. dan Chen, H. (2010). Bioactive alginate coatings to control Listeria monocytogenes on coldsmoked salmon slices and fillets. International Journal of Food Microbiology 136: 326-331.

Ojagh, S.M., Rezaei, M., Razavi, S.H. dan Hosseini, S.M.H. (2010). Effect ofchitosan coatings enriched with cinnamon oil on the quality of refrigerated rainbow trout. Food Chemistry 120: 193-198.

Perez, E., Schultz, F.S. dan Delahaye, E.P. (2005). Characterization of some properties of starches isolated from Xanthosoma sagittifolium (tannia) and Colocassia esculenta (taro). Carbohydrate Polymers 60(2): 139145.

Shen, X.L., Wu, J.M., Chen, Y. dan Zhao, G. (2010). Antimicrobial and physical properties of sweet potato starch films incorporated with potassium sorbate or chitosan. Food Hydrocolloids 24: 285-290.

Song, Y., Liu, L., Shen, H., You, J. dan Luo, Y. (2011). Effect of sodium alginate-based edible coating containing different anti-oxidants on quality and shelf life of refrigerated bream (Megalobrama amblycephala). Food Control 22: 608-615.

Suppakul, P., Jutakorn, K. dan Bangchokedee, Y. (2010). Efficacy of cellulose-based coating on enhancing the shelf life of fresh eggs. Journal of Food Engineering 98: 207-213.

Warkoyo, Rahardjo, B., Marseno, D.W. dan Karyadi, J.N.W. (2014). Sifat fisik, mekanik dan barrier edible film berbasis pati umbi kimpul (Xanthosoma sagittifolium) yang diinkorporasi dengan kalium sorbat. Agritech 34(1): 72-81.

Warkoyo, Rahardjo, B., Marseno, D.W. dan Karyadi, J.N.W. (2015). Kinetika pertumbuhan mikrobia dan kemunduran mutu bakso daging terlapisi pati umbi kimpul (Xanthosoma sagittifolium) yang diinkorporasi dengan kalium sorbat. Agritech 35(1): 61-68.

Warsiki, E., Sunarti, T.C. dan Martua, R.D. (2009). Pengembangan kemasan antimicrobial (AM) untuk memperpanjang umur simpan produk pangan. Prosiding Seminar Hasil-Hasil Penelitian IPB. 579-588.

Yousef, A.E. dan Carlstrom, C. (2003). Food Microbiology: a Laboratory Manual. A John Wiley and Sons., Inc. Publication, USA. 